\title{
A Study of Typhoid Fever in Bheri Zonal Hospital and Nepalgunj Medical College Teaching Hospital, Banke, Nepal
}

\author{
${ }^{1}$ Gaurav Jung Shah, ${ }^{2}$ Thakur Prasad Poudel \\ ${ }^{1}$ Department of Community Medicine, Nepalgunj Medical College, Nepalgunj, Banke, Nepal \\ ${ }^{2}$ Department of Microbiology, Nepalgunj Medical College, Nepalgunj, Banke, Nepal
}

\begin{abstract}
Typhoid fever remains an important public health issue in many developing countries and predominates in areas with poor sanitation, which aids its transmission and persistencein the human population. The prevalence of typhoid fever in different months of a year (2009/2010) and the distribution of cases of typhoid fever with respect to their age and gender among patients visiting Nepalgunj Medical College Teaching Hospital (NGMCTH) and Bheri Zonal Hospital (BZH), the two major health delivering institutions of Mid-western and Far-western regions of Nepal. During this period, 4657 and 5496 blood samples were collected in NGMCTH and BZH respectively. Of the 4657 tested in NGMCTH, agglutinins to Salmonella typhi was observed in 1092 samples (overall prevalence rate being 23.45\%), that were most prevalent in months corresponding to wet season (June/ July-31\%, July/August-29.65\%). Similar trend was observed for BZH where of 5496 samples tested, Salmonella typhi was positive in 1814 samples with overall prevalence rate being $31.77 \%$, cases being most prevalent in months corresponding to wet season (June/July-45.91\%, July/August - 47.41\%). In both hospitals, there was male predominance among cases (Male to Female Sex-ratio: 224:100 for NGMCTH and 247:100 for BZH). This male predominance was maintained in almost all age-groups. There was high proportion of cases of less than 30 years of age in both NGMCTH and BZH (77.84\% and 73.98\% respectively) indicating that most of the cases of typhoid fever are of younger age-group.On the average, typhoid cases aged 24.58 years \pm 13.00 years for NGMCTH, while for BZH it was 25.81 years \pm 13.41 years. Mean age of females was found to exceed to that of males in both NGMCTH (26.84 years \pm 12.31 years against 23.58 years \pm 13.16 years) and BZH (27.61 years \pm 13.64 years against 25.08 years \pm 13.25 years).
\end{abstract}

Key words: Salmonella typhi, widal test, incidence, Nepal.

Corresponding address : Gaurav Jung Shah, Department of Community Medicine, Nepalgunj Medical College, Banke, Nepal E-mail: jshah_gaurav@hotmail.com

\section{INTRODUCTION}

Typhoid Fever is an acute infectious disease caused by the typhoid bacillus Salmonella typhi. The bacillus is transmitted by milk, water, or solid food contaminated by feces of typhoid victims or of carriers, that is, healthy persons who harbor typhoid bacilli without presenting symptoms. Typhoid fever was an important cause of illness and death in the overcrowded and unsanitary urban conditions of the United States and Europe in the $19^{\text {th }}$ century. World Health Organization (WHO) conservatively estimates the annual global incidence of typhoid fever at $0.3 \%$. Typhoid fever remains an important public health issue in many developing countries and predominates in areas with poor sanitation, which aids its transmission and persistence in the human population. ${ }^{1-3}$ The disease is highly prevalent in South-central and South east Asia ${ }^{4}$ attributed mainly to poor sanitary and hygienic condition particularly due to contamination of drinking water supplies. ${ }^{5}$ In some developing countries of Asia and Africa the annual incidence may reach $1 \%$ with case fatality rate as high as $10 \%$. About $70 \%$ of all fatalities from typhoid fever occurs in Asia. This results in the global estimate of more than 16 million cases of typhoid fever occurring annually, causing 600,000 deaths. ${ }^{1,6,7}$
In Nepal typhoid fever is prevalent in mountains, valleys and southern belts of the country as an endemic disease with its peak incidence in May to August and is one of the leading diagnoses of fever in most of the hospitals in Nepal. ${ }^{8,9}$ Typhoid outbreak was responsible for the deaths of many Nepalese from the time it was known as one of the causes of the fever. However, typhoid fever was considered responsible for deaths of many patients admitted in the hospitals in Kathmandu, the capital of Nepal, in late 1960s when the National Public Health Laboratory (NPHL) came into being. We estimate that the prevalence of typhoid fever in some parts of Kathmandu, Nepal is amongst the highest in South Asia. ${ }^{2,10}$ A ten year study was recently reported in which 9,124 invasive Salmonella isolates were recovered from 12,252 positive blood cultures taken at Patan Hospital in Kathmandu in 1993-2002. ${ }^{11}$ The majority of isolates were confirmed as S. typhi. There have been reports of seasonal typhoid outbreaks, recently in 2002 in Bharatpur, a town in Central Nepal which was the largest single-point source outbreak of multidrug-resistant (plasmid encoded single point mutation) typhoid fever associated with contamination of municipality water supply affecting more than 6,000 patients in a 4 to 5 weeks period. ${ }^{8,12-14}$ 


\section{MATERIALS AND METHODS}

This study involves comparison of frequency and distribution of typhoid fever cases between Nepalgunj Medical College Teaching Hospital (NGMCTH) and Bheri Zonal Hospital (BZH) in Nepalgunj for the fiscal year 2066/67 B.S. (July 2009/2010).The diagnostic criteria of typhoid fever was based on finding of the slide test type of Widal test, which would detect antibodies against $\mathrm{O}$ and $\mathrm{H}$ antigens of $S$. typhi and $\mathrm{H}$ antigen of S. paratyphi A and S. paratyphi B. The samples which showed agglutination (clumping) with the antigenic reagents were considered positive and those that do not agglutinated were considered negative. Information on age and sex of all positive cases was tracked and recorded from outpatients and inpatients records of the hospitals. Mean of numeric variable is expressed in the format (Mean \pm Standard Deviation). For independence of categorical variables Pearson's Chi-square $\left(\chi^{2}\right)$ test of independence was performed and confidence intervals (CI) were determined by using Student's ' $t$ ' distribution for numeric variables and by using normal approximation with Wilson calculation method for categorical variables.

The statistical analysis of the obtained data was done with IBM SPSS 19 for Microsoft Windows and Microsoft Office Excel 2007 for Windows.

\section{RESULTS}

There were a total of 4657 patients in NGMCTH, Nepalgunj who went through blood test with Widal test, among them 1092 were positive. Among 5496 patients undergoing the Widal test in Bheri Zonal Hospital, 1814 were positive. The distribution of positive cases in different months of the study period for both the hospitals is shown in Table 1.

Table 1: Monthly distribution of typhoid cases in NGMCTH and Bheri Zonal Hospital (2009/2010)

\begin{tabular}{|c|c|c|c|c|c|c|c|c|c|c|}
\hline \multirow{3}{*}{ Months } & \multicolumn{5}{|c|}{ NGMCTH } & \multicolumn{5}{|c|}{$B Z H$} \\
\hline & \multirow[b]{2}{*}{\begin{tabular}{|} 
Samples \\
examined
\end{tabular}} & \multirow{2}{*}{$\begin{array}{c}\text { Positive } \\
\text { cases }\end{array}$} & \multirow{2}{*}{$\begin{array}{l}\text { Prevalence } \\
\text { Rate }(\%)\end{array}$} & \multicolumn{2}{|c|}{$95 \% C I$} & \multirow[b]{2}{*}{$\begin{array}{c}\text { Samples } \\
\text { examined }\end{array}$} & \multirow[b]{2}{*}{$\begin{array}{c}\begin{array}{c}\text { Oositive } \\
\text { cases }\end{array} \\
\text { cats }\end{array}$} & \multirow{2}{*}{$\begin{array}{c}\text { Prevalence } \\
\text { Rate } \\
(\%)\end{array}$} & \multicolumn{2}{|c|}{$95 \% \mathrm{CI}$} \\
\hline & & & & \begin{tabular}{|l}
$\begin{array}{l}\text { Lower } \\
\text { Limit }\end{array}$ \\
\end{tabular} & \begin{tabular}{|c|}
$\begin{array}{c}\text { Upper } \\
\text { Limit }\end{array}$ \\
\end{tabular} & & & & 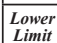 & $\begin{array}{l}\text { Upper } \\
\text { Limit }\end{array}$ \\
\hline July/August & 317 & 94 & 29.65 & 24.89 & 34.90 & 386 & 183 & 47.41 & 42.48 & 52.39 \\
\hline \begin{tabular}{|l|} 
August/September \\
\end{tabular} & 532 & 79 & 14.85 & 12.08 & 18.12 & 599 & 131 & 21.87 & 18.74 & 25.35 \\
\hline September/October & 496 & 116 & 23.39 & 19.88 & \begin{tabular}{|l|}
27.31 \\
\end{tabular} & 586 & 193 & 32.94 & 29.25 & 36.84 \\
\hline October/November & 397 & 83 & 20.91 & 17.19 & 25.18 & 462 & 138 & 29.87 & 25.88 & 34.20 \\
\hline November/December & 301 & 87 & 28.90 & 24.07 & \begin{tabular}{|l|}
34.27 \\
\end{tabular} & 365 & 158 & 43.29 & 38.30 & 48.41 \\
\hline December/January & 182 & 39 & 21.43 & 16.09 & 27.95 & 213 & 47 & 22.07 & 17.02 & 28.10 \\
\hline \begin{tabular}{|l|} 
January/February \\
\end{tabular} & 247 & 62 & 25.10 & 20.10 & \begin{tabular}{|l|}
30.86 \\
\end{tabular} & 294 & 95 & 32.31 & 27.22 & 37.86 \\
\hline February/March & 396 & 100 & 25.25 & 21.23 & \begin{tabular}{|l|}
29.76 \\
\end{tabular} & 472 & 202 & 42.8 & 38.41 & 47.30 \\
\hline March/April & 410 & 92 & 22.44 & 18.67 & 26.72 & 482 & 135 & 28.01 & 24.19 & 32.18 \\
\hline April/May & 463 & 83 & 17.93 & 14.70 & \begin{tabular}{|l|}
21.68 \\
\end{tabular} & 530 & 101 & 19.06 & 15.94 & 22.62 \\
\hline May/June & 458 & 115 & 25.11 & \begin{tabular}{|l|l|}
21.36 \\
\end{tabular} & \begin{tabular}{|l|}
29.28 \\
\end{tabular} & 545 & 173 & 31.74 & \begin{tabular}{|l|}
27.97 \\
\end{tabular} & 35.77 \\
\hline June/July & 458 & 142 & 31.00 & 26.94 & 35.38 & 562 & 258 & 45.91 & 41.83 & 50.04 \\
\hline Total & 4657 & 1092 & 23.45 & 22.25 & \begin{tabular}{|l|}
24.69 \\
\end{tabular} & 5496 & 1814 & 33.01 & 31.77 & 34.26 \\
\hline
\end{tabular}

The highest number of typhoid cases was observed in the month of June/July in both NGMCTH and BZH (142 and 258 respectively). This was followed byFebruary/March (202 cases) and September/October (193 cases) in BZH and September/October (116 cases) and May/June (115 cases) in NGMCTH. Similarly, least count of cases was recorded in both hospitals in the same period (December/January), the figures being 39 and 47 respectively. Figure 1 depicts the trend in monthly distribution of positive cases for the two hospitals studied.

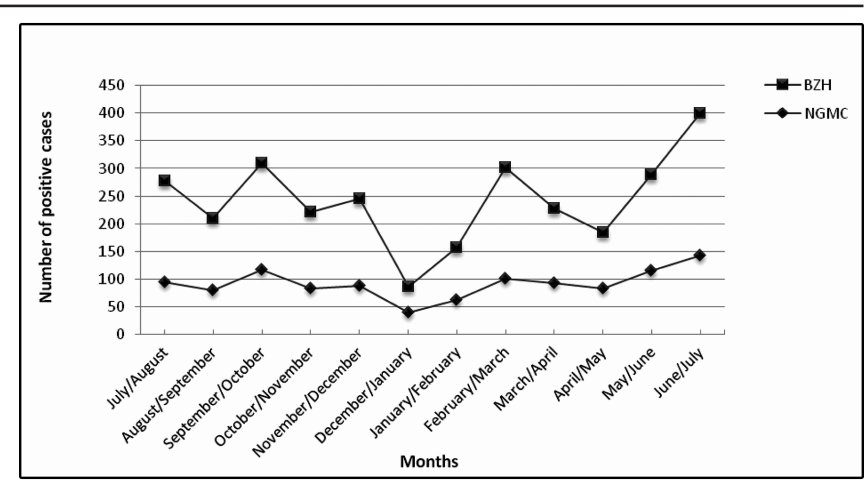

Figure 1: Variation in number of typhoid cases in different months

The prevalence rate of typhoid fever was found highest in June/July for NGMCTH (31\%; $95 \%$ CI being $26.94 \%$ to $35.38 \%$ ), however, for BZH, prevalence rate of typhoid fever was at its peak ( $47.41 \%$; $95 \%$ CI being $42.48 \%$ to $52.39 \%$ ) in July/August. Monthly prevalence rate of typhoid fever, along with $95 \%$ confidence interval estimate for both hospitals is also summarized in Table 1 above. Differences in monthspecific prevalence rates of typhoid fever among different months of the study period was statistically significant (with p-values $<0.0001$ for both hospitals) for both the hospitals.

The age and gender distribution of typhoid fever cases for both hospitals is summarized in Table 2. The overall male to female ratio was $224: 100$ for NGMCTH and 247:100 for BZH. In NGMCTH for all age-groups, male to female sexratio was found in favor of males (except in age-group 61 to 70 years which had a sex ratio of 75:100) while in BZH male to female sex-ratio favored females for age-groups 31 to 40 years and 71 to 80 years $(60: 100$ and 67:100) and favored males for other age-groups. The percentage of typhoid cases was highest for 21 to 30 years age-group in NGMCTH as well as BZH ( $39.47 \%$ and $36.22 \%$ respectively), with $77.84 \%$ cases and $73.98 \%$ cases belonging to less than 30 years agegroup alone, respectively.

Table 2: Age and Sex distribution and age-specific mean age of cases of typhoid fever for NGMCTH and BZH (2009/2010)

\begin{tabular}{|c|c|c|c|c|c|c|c|c|c|c|c|c|}
\hline \multirow{2}{*}{ Age (years) } & \multicolumn{6}{|c|}{ NGMCTH } & \multicolumn{6}{|c|}{$B Z H$} \\
\hline & \begin{tabular}{|l|} 
Male \\
\end{tabular} & $\%$ & Female & $\%$ & Total & $\%$ & Male & $\%$ & Female & $\%$ & Total & $\%$ \\
\hline$<10$ & 116 & 87.88 & 16 & 12.12 & 132 & 12.09 & 142 & 84.52 & 26 & 15.48 & 168 & 9.26 \\
\hline 11 to 20 & 206 & 71.78 & 81 & 28.22 & 287 & 26.28 & 356 & 68.86 & 161 & 31.14 & 517 & 28.50 \\
\hline 21 to 30 & 278 & 64.50 & 153 & 35.50 & 431 & 39.47 & 506 & 77.02 & 151 & 22.98 & 657 & 36.22 \\
\hline 31 to 40 & 56 & 55.45 & 45 & 44.55 & 101 & 9.25 & 59 & 37.58 & 98 & 62.42 & 157 & 8.65 \\
\hline 41 to 50 & 67 & 77.91 & 19 & 22.09 & 86 & 7.88 & 170 & 80.57 & 41 & 19.43 & 211 & 11.63 \\
\hline 51 to 60 & 27 & 60.00 & 18 & 40.00 & 45 & 4.12 & 51 & 56.04 & 40 & 43.96 & 91 & 5.02 \\
\hline 61 to 70 & 3 & 42.86 & 4 & 57.14 & 7 & 0.64 & 6 & 75.00 & 2 & 25.00 & 8 & 0.44 \\
\hline 71 to 80 & 2 & 66.67 & 1 & 33.33 & 3 & 0.27 & 2 & 40.00 & 3 & 60.00 & 5 & 0.28 \\
\hline Total & \begin{tabular}{|l|}
755 \\
\end{tabular} & 69.14 & 337 & 30.86 & 1092 & 100 & 1292 & 71.22 & 522 & 28.78 & 1814 & 100 \\
\hline Statistics & \multicolumn{2}{|c|}{ Male } & \multicolumn{2}{|c|}{ Female } & \multicolumn{2}{|c|}{ Total } & \multicolumn{2}{|c|}{ Male } & \multicolumn{2}{|c|}{ Female } & \multicolumn{2}{|c|}{ Total } \\
\hline $\begin{array}{l}\text { Mean } \pm \\
\text { Standard } \\
\text { deviation }\end{array}$ & \multicolumn{2}{|c|}{$23.58 \pm 13.16$} & \multicolumn{2}{|c|}{$26.84 \pm 12.31$} & \multicolumn{2}{|c|}{$24.58 \pm 13.00$} & \multicolumn{2}{|c|}{$25.08 \pm 13.25$} & \multicolumn{2}{|c|}{$27.61 \pm 13.64$} & \multicolumn{2}{|c|}{$25.81 \pm 13.41$} \\
\hline $\begin{array}{l}\text { 95\% Confidence } \\
\text { interval of } \\
\text { mean }\end{array}$ & \multicolumn{2}{|c|}{22.64 to 24.52} & \multicolumn{2}{|c|}{25.52 to 28.16} & \multicolumn{2}{|c|}{23.81 to 25.35} & \multicolumn{2}{|c|}{24.36 to 25.80} & \multicolumn{2}{|c|}{26.44 to 28.78} & \multicolumn{2}{|c|}{25.19 to 26.43} \\
\hline
\end{tabular}

Mean age of typhoid cases was 24.58 years \pm 13.00 years for NGMCTH, while for BZH it was 25.81 years \pm 13.41 
years. This gave $95 \%$ confidence interval estimate of 23.8081 years to 25.3519 years for NGMCTH and 25.1925 years to 26.4275 years for BZH (Table 2). In NGMCTH, a total of 755 male cases had mean age of 23.58years \pm 13.16 years (95\% CI: 22.6398 years to 24.5202 years) while their 337 female counterparts had mean age of 26.84years \pm 12.31 years (95\% CI: 25.5210years to 28.1590years). These figures for BZH were 25.08 years \pm 13.25 years $(95 \%$ CI: 24.3568 years to 25.8032 years) and 27.61years \pm 13.64 years (95\% CI: 26.4372 years to 28.7828 years) respectively for 1292 males and 522 females.

\section{DISCUSSION}

Typhoid fever is a major health problem in developing countries attributed to poor sanitary and hygienic conditions including lack of potable water. In Nepal, drinking water sources (piped, natural taps/spouts and wells) are heavily contaminated..$^{15-17}$ In the cities, contamination of water is resulted due to cross-contamination with sewerage. ${ }^{18}$ Still, in many communities, most of households do not have latrines. ${ }^{19}$ Therefore, the disease has remained endemic with outbreaks occurring time and again. ${ }^{3,20-22}$

In this study there was a seasonal signal in the monthly frequency of typhoid fever cases. In Nepalgunj, rainy season usually spans over the months of June, July and August with the peak of the wet season occurring in July, which corresponds with a peak number of cases (Figure 1) in July in both NGMCTH and BZH (142 and 258 cases respectively). Also higher frequency of cases was observed during September/October (116 and 193 respectively) when the rainy season starts to subside, February/March (100 and 202 cases respectively) that corresponds to start of summer season and May/June (115 and 173respectively) when the rainy season begins. Nepalgunj is one of the hottest cities of Nepal that was not developed based on proper town-planning system. It has been always facing problems of improperly constructed buildings and roads with no properly managed gutter waste disposal and water logged areas. As the wet season ends, the water level progressively gets lower becoming more stagnant and shallow and deteriorating further due to hot temperature. Salmonella typhi is spread by the fecal-oral route. Following acute infections, patients may continue to excrete $S$. typhi for several weeks or for years as a chronic carrier. ${ }^{23}$ Under such conditions, one would expect the contamination of water by S. typhi. Since there is almost no trend of households using boiled water for drinking, the likelihood of ingesting $S$. typhi from contaminated water is high. ${ }^{15-17}$ Our findings also collaborate with a number of studies performed before..$^{3,20-22}$ A similar hospital based study in Kathmandu and a study in Pakistan had indicated seasonal influence on the occurrence of typhoid cases. ${ }^{24,25}$ Similar observations were also made in Indonesia where increased rainfall was followed by a peak of typhoid fever cases five months later when the rainfall was the lowest. ${ }^{26}$

Iqbal et. al., ${ }^{27}$ quoted male to female ratio as 400:100 in their case series of 52 typhoid patients. These findings are also supported by $\mathrm{Khosla}^{28}$ who described that this male preponderance may be due to greater chances of exposure to male population who go out of the house much frequently than females for eating food from restaurants and Street vendors. Previous reports from Nepal including recent one have shown higher prevalence of Salmonellosis in males than in females. ${ }^{22,29-31}$ In our study the male to female ratio among the cases were 224:100 and 247:100 for NGMCTH and BZH respectively, which is consistent with and comparable to the above cited studies. This same trend in the distribution of male and female cases was observed in almost all agegroups of the two hospitals, with this sex differential being statistically significant in both cases (p-value $<0.0001$ for both NGMCTH and BZH). Exemptions were for the agegroup 61 to 70 years for NGMCTH (sex ratio being 75:100) and 31 to 40 and 71 to 80 for BZH (sex ratio being 60:100 and 67:100 respectively). Higher positive rate among males has also been reported among children attending a children hospital in Kathmandu. ${ }^{32}$ More outdoor exposure of males has been given the possible reason for higher positive rate among them. The reason for such discrepancy demands further investigation. Slightly higher prevalence among females, mostly pregnant women, is reported from Pakistan and has been explained on the basis of increased susceptibility to infection during pregnancy. ${ }^{33}$

In our study, there was high proportion of cases of less than 30 years of age in both NGMCTH and BZH (77.84\% and 73.98\% respectively) indicating that most of the cases of typhoid fever are of younger age-group. This was also evident by the fact that mean age of typhoid cases was 24.58 years \pm 13.00 years for NGMCTH, while for BZH it was 25.81 years \pm 13.41 years. This finding collaborate with the study in which Khan et al reported that main group of patients in their study was of younger age, where 18 out of 22 patients (64\%) were below 32 years of age. A recent study from Indonesia regarding the high risk groups and high risk behaviors concluded that the median age of the cases was 22 years. ${ }^{26,34}$ Further, the mean age for females exceeded to that of males in both hospitals (NGMCTH: 26.84years \pm 12.31 yearsfor females, 23.58years \pm 13.16years for males; BZH: 27.61years \pm 13.64 years for females, 25.08years \pm 13.25 years for males). This difference in mean age between male and female cases was found to be statistically significant ( $p$-value $<0.0001$ for NGMCTH and $<0.001$ for BZH) suggesting that female cases of typhoid fever were, on the average, older than their male counterparts.

\section{CONCLUSION}

From the findings of our study it could be concluded that typhoid fever mainly affects the younger age group. Males are affected more with this febrile illness. There exists seasonal influence on its occurrence with higher prevalence in summer and rainy seasons. Typhoid fever or acute febrile illness caused by Salmonella typhi is an important cause of community-acquired septicemia, morbidity and mortality in Nepal as in many asian countries. To avert the increasing morbidity and mortality from typhoid fever, clinicians and health workers need to work together to raise awareness about the risk factors of typhoid fever. The study may be useful to public health agencies in planning infectious disease prevention and control strategies. Treated sources of domestic and drinking water are very important in rural areas where these facilities are lacking. Awareness programs on basic rules of hygiene for semi-urban and rural communities of economically poor nations should be encouraged so as to limit the transmission of fecal-orally transmitted infections. 


\section{REFERENCES}

1. Parry CM, Hien TT, Dougan G, White NJ, Farrar JJ. Typhoid Fever. The NEJ Med. 2002; 347:1770-1782.

2. Karkey A, Aryjal A, Basnyat B, Baker S. Kathmandu, Nepal; Still an Enteric Fever Capital of the World. J Infect Dev Ctries. 2008; 2(6):461-465.

3. Lewis MD, Serichantalergs O, Pitarangsi C, Chuanak N, Mason CJ, Regmi LR et. al. Typhoid fever: a massive, singlepoint source, multidrug-resistant outbreak in Nepal. Clin Infect Dis 2005; 40: 554-61.

4. Crump JA, Luby SP, Mintz ED. The global burden of typhoid fever. Bull WHO. 2004; 82:346-53.

5. Background document. The diagnosis, treatment and prevention of typhoid fever. Geneva: WHO; 2003.

6. WHO. Typhoid fever. A report of WHO expert committee. WHO Technical Report Series 149. Geneva: WHO; 1997.

7. Ivanoff B. Typhoid fever: global situation and WHO recommendations. Southeast Asian J Trop Med Public Health. 1995; 26:1-6.

8. Hale T. Time and Money - Developing World Ethics. Nucleus. 1999; 10-14.

9. Rauniar GP, Das BP, Baral DD, Naga Rani MA. Treatment pattern of typhoid fever at a tertiary care teaching hospital in eastern Nepal. J Nepal Med Asso. 2000; 39:218-221.

10. Maskey AP, Day JN, Phung QT, Thwaites GE, Campbell JI, Zimmerman M, Farrar JJ, Basnyat B. Salmonella entericaserovar Paratyphi A and S entericaserovartyphi cause indistinguishable clinical syndromes in Kathmandu, Nepal. Clin Infect Dis 2006; 42(9):1247-1253.

11. Maskey AP Basnyat B, Thwaites GE, Campbell JI, Farrar JJ, Zimmerman MD. Emerging trends in enteric fever in Nepal: 9124 cases confirmed by blood culture 1993-2003.Trans R Soc Trop Med Hyg. 2008; 102(1):91-95.

12. Lewis M, Mason C. Pitarangsi C. AFRIMS determines epidemics in Nepal is Typhoid. Global Emerging Infections System 2002.

13. Threlfall EJ, Ward LR, Rowe B, Raghupathi S, Chandrasekaran V, Vandepitte J et. al. Wide spread occurrence of multiple drug resistance Salmonella typhi in India. Eur J ClinMicrobiol Infect Dis. 1992; 11:990-993.

14. Gulati S, Marwaha RK, Prakash D, Ayyagari A, Singhi S, Kumar L et. al. Multi drug-resistant Salmonella typhi-a need for therapeutic reappraisal. Ann Trop Paediatr 1992; 12:137-141.

15. Adhikari RK, Rai SK, Pokhrel BM, Tuladhar NR, Khadka JB, Upadhyay MP. Bacterial study of drinking water of Kathmandu Valley. J Inst Med (Nepal). 1986; 8:313-6.

16. Ono K, Rai SK, Chikahira M, Fujimoto T, Shibata H, Wada Y et. al. Seasonal distribution of enteropathogens detected from diarrheal stool and water samples collected in Kathmandu, Nepal. Southeast Asian J Trop Med Public Health 2001; 32:520-6.

17. Ghimire G, Pant J, Rai SK, Choudhary DR, Adhikari N. Bacteriological analysis of water of Kathmandu Valley. JNAMLS. 2007; 8:45-7.

18. Rai SK, Shrestha HG, Nakanishi M, Kubo T, Ono K, Uga S, Matsumura T. Hookworm infection recorded at an University Teaching Hospital in Kathmandu, Nepal over one decade period. Japanese J Trop Med Hyg. 1997; 25:81-4.

19. Rai SK, Nakanishi M, Upadhyay MP, Rai CK, Hirai K, Ohno Y et. al. Effect of intestinal helminth infection on some nutritional parameters among rural villagers in Nepal. Kobe J Med Sci (Japan). 1998; 44:91-8.

20. Murdoch DR, Woods CW, Zimmerman MD, Dull PM, Belbase RH, Keenan AJ et. al. The etiology of febrile illness in Adults presenting to Patan hospital in Kathmandu, Nepal. Amer J Trop Med. Hyg. 2004; 70:670-5.

21. Malla S, Kansakar P, Serichantalergs, Rahman M, Basnet S. Epidemiology of typhoid and paratyphoid fever in Kathmandu: two years study and trends of antimicrobial resistance. JNMA. 2005; 44:18-22.

22. Prajapati B, Rai GK, Rai SK, Upreti HC, Thapa M, Singh G et. al. Prevalence of Salmonella typhi and paratyphi infection in children: a hospital based study, NMCJ. 2008; 10:238-41.

23. Edelman R, Levine MM. Summary of an international workshop on typhoid fever. Rev of Infect Dis. 1986; 8:329-349.

24. Karkey A, Arjyal A, Anders KL, Boni MF, Dongol S, Koirala S, My PV, Nga TV, Clements AC, Holt KE, Duy PT, Day JN, Campbell JI, Dougan G, Dolecek C, Farrar J, Basnyat B, Baker S. The Burden and Characteristics of Enteric Fever at a Healthcare Facility in a Densely Populated Area of Kathmandu. PLoS ONE. 2010; Vol. 5 Issue 11: p1.

25. Siddiqui FJ Rabbani F, Hasan R, Nizami SQ, Bhutta ZA Typhoid fever in children: some epidemiological considerations from Karachi, Pakistan. Int J Infect Dis. 2006; 10(3):215-222.

26. Velema JP, Van-Wynen G, Bult P, Van-Naerssen T, Jota S. Typhoid fever in Ujung Pandag Indonesia-high risk groups and high risk behaviors. Trop Med Int Health.1997 Nov; 2(11):1088-94.

27. Iqbal M, Rasool I, Shaukat, Rehman H \& Tabriz. Surgical treatment of typhoid ileal perforation. JPMA. 1988; $38: 316$.

28. Khosla SN. Changing pattern of typhoid fever. Asian Medical J. 1982; 25(3):185-89.

29. Sharma N, Koju R, Karmacharya B, Tamang MD, Makaju R, Nepali N et. al. Typhoid fever in Dhulikhel Hospital, Nepal. Kathmandu Univ Med J. 2003; 2:188-92.

30. Shakya KN, Baral MR, Shrestha R. A study of atypical manifestations of enteric fever in children. JNHRC. 2008; 6:1-4.

31. Sharma NP, Peacock SJ, Phumratanaprapin W, Day N, White N, Pukrittayakamee S. A hospital-based study of bloodstream infections in febrile patients in Dhulikhel Hospital, Kathmandu University Teaching Hospital, Nepal. Southeast Asian J Trop Med Public Health. 2006; 37:351-6.

32. Sharma AK. Antimicrobial resistance pattern of Salmonella in Kanti Children's Hospital: which drug to choose? J Nepal Pediatr Soc. 2006; 1:20-3.

33. Khanum S, Saba N, Qayyum M, Islam B, Qazilbash AA. Distribution patterns of Salmonella infection in Rawalpindi/ Islamdbad area and the risk factors associated with the disease prevalence. J Biol Sci. 2006; 6:253-60.

34. Khan AS, Rukhsana and Rana SA. Typhoid perforation. Results of surgical treatment. JPMA. 1982; 32:46-47. 